\title{
CHANGES IN SPRING WHEAT (Triticum aestivum ssp. vulgare L.) AND PERSIAN CLOVER (Trifolium resupinatum L.) BIOMASS UNDER THE INFLUENCE OF PLANT COMPETITION AND DENSITY
}

\author{
Maria Wanic, Monika Myśliwiec \\ University of Warmia and Mazury in Olsztyn, Department of Agricultural Systems \\ Plac Łódzki 3, 10-718 Olsztyn, Poland \\ e-mail: maria.wanic@uwm.edu.pl
}

Received: 31.03 .2014

\begin{abstract}
The influence of sowing method and plant density on the biomass of spring wheat and Persian clover was evaluated. In a pot experiment conducted in three series during the years 2010-2012, plants were cultivated as mixed and pure crop at higher (consistent with agronomic recommendations) and lower density, decreased by $20 \%$ compared to it. Dry mass accumulation tests for both species were conducted during the following wheat growth stages (BBCH): leaf development (12-14), tillering (21-23), stem elongation (31-32), inflorescence development (54-56), and ripening (87-89). Based on the results obtained, the biomass growth rate for both species in question was also determined. It was shown that the mass of shoots of spring wheat cultivated as mixed crop was lower than that of wheat shoots grown as pure crop during the stem elongation and ripening stages. Mixed sowing limited aboveground accumulation in the heads and grain the most and in the stems the least. During the leaf development and stem elongation stages, the wheat presented a more pronounced response to the presence of clover expressed by biomass decrease in case of the treatment with lower plant density and during ripening in the treatment with recommended plant density. In case of both sowing methods and plant densities, the mass of wheat roots was similar. Biomass accumulation in Persian clover shoots and roots in mixed sowing was lower than in pure crop during the entire growing period. The wheat limited biomass accumulation of Persian clover in inflorescences the strongest and in the roots the least. The spring wheat growth rate in both sowing methods was similar as opposed to Persian clover in the case of which a decrease in the growth rate was observed in the mixed crop during the generative development period.
\end{abstract}

Key words: Triticum aestivum, Trifolium resupinatum, mixture, density, growth stages, biomass, plant growth rate

\section{INTRODUCTION}

Currently, intercropping is seen as a component increasing ecosystem biodiversity and stability, while its importance as the forage source is treated as secondary $[1,2]$. Different species of plants and their different forms can be applied as intercrops. Papilionaceous plants, particularly clovers, are frequently applied in mixed sowing because of their positive influence on the soil environment and the main crop (which in most cases is a cereal) $[3,4]$. Their positive role is mainly represented by fixing atmospheric nitrogen which is then built into their structure, making it available to the accompanying plants and enriching the soil with this element. Different interactions, however, take place between the components of a mixed crop which result in changes in the development rhythm, morphology, biomass and yield of the plants. Competition is a trophic phenomenon commonly present in the nature. In the recent years, numerous studies have been published on interactions of this type in phytocenoses [5-9]. However, relatively few data can be found on the competition between cereals and interseeded plants, particularly papilionaceous species $[3,10]$. Moreover, the competition is examined in most cases during the initial or final period of mixed growth. Hence, the literature on the development of this interaction throughout the entire growing period and the influence of plant density on the process is rather limited $[4,11]$. Investigating the competition between spring wheat and Persian clover throughout the entire period of their mixed growth at different densities of species will allow us to optimize the agricultural technique, ensuring high yields of intercrops.

Given the above, a research hypothesis was formulated assuming that competition would occur between spring wheat and Persian clover and that the intensity of the interaction would depend on the growth stage and plant density. It was verified based 
on an experiment aimed to evaluate the influence of mixed cropping of spring wheat and Persian clover on biomass accumulation in different aboveground parts and roots throughout the entire period of their mixed growth under conditions of different plant densities.

\section{MATERIALS AND METHODS}

The study was based on a pot experiment conducted in three series at the greenhouse laboratory of the University of Warmia and Mazury in Olsztyn. It was conducted during the following periods: series I from 12.04 to 19.07.2010; series II from 24.03 to 30.06.2011; and series III from 26.03 to 28.06.2012. Spring wheat Triticum aestivum (Nawra cultivar) and Persian clover Trifolium resupinatum (Gobry cultivar) were cultivated as pure and mixed crop in two density variants: recommended and decreased by $20 \%$.

The experimental factors were as follows:

I. spring wheat and Persian clover cultivation method:

- pure crop

- mixed crop

II. plant density:

- higher (according to agronomic recommendations) - in the paper referred to as "recommended"

- lower (decreased by $20 \%$ as compared to the recommended density).

The tests were conducted during 5 periods determined by the growth stages of spring wheat sown as pure crop at the recommended density, i.e. (according to $\mathrm{BBCH})$ : leaf development (12-14), tillering (21-23), stem elongation (31-32), inflorescence emergence (54-56), and ripening (87-89).

The experiment was established according to the additive model according to which the number of plants in the mixture was the sum of their numbers in the pure crop. This experimental design allowed us to study the interaction between spring wheat and Persian clover from the beginning of growth and eliminated the effect of intraspecific competition on the competition process development [12].

The experiment consisted of 120 pots (two species in pure crop and in mixture $\mathrm{x}$ two sowing densities $x 5$ growth stages $\mathrm{x} 4$ replications). The experiment used Kick-Brauckmann pots, $22 \mathrm{~cm}$ in diameter and $25 \mathrm{~cm}$ deep. The seeds were sown at an equal distance from each other (according to the template) and placed in the soil at a depth of $3 \mathrm{~cm}$ - spring wheat, and $1 \mathrm{~cm}-$ Persian clover. In the pots with the recommended density, 19 seeds of spring wheat and 12 seeds of Persian clover were sown. The numbers in the lower density pots were 15 and 9 , respectively. This corresponded to the density per $1 \mathrm{~m}^{2}$ : spring wheat at a recommended density of 500 and at a lower density of 400 , while for Persian clover it was 300 and 240, respectively.

The soil material consisted of brown leached soil developed from heavy clay with the contents of floatable fraction at $64 \%$, silt $12 \%$, and sand $24 \%$. This soil was characterized by the organic carbon content from $1.06 \%$ to $1.46 \%$, slightly acid reaction $(\mathrm{pH}$ in $1 \mathrm{M} \mathrm{KCl}$ from 5.6 to 6.2), and the following nutrient availability $\left(\mathrm{mg} \times 100 \mathrm{~g}^{-1}\right.$ soil): high availability of phosphorus (9.2-11.6) and magnesium (8.8-9.1), and medium availability of potassium (12.9-14.5). To fill the pots, the soil was collected from the depth of $0-25 \mathrm{~cm}$.

Mineral NPK fertilization was applied once one week before the sowing date. For this purpose, an aqueous solution of urea, monopotassium phosphate, and potassium sulphate were prepared and added at appropriate rates to the soil which was then thoroughly mixed and put into the pots. Identical fertilization with phosphorus and potassium at the following rates $\left(\mathrm{g} \times\right.$ pot $\left.^{-1}\right): \mathrm{P}-0.200$ and $\mathrm{K}-0.450$, was applied to all the pots. The nitrogen dose varied depending on the species and sowing method and it was as follows $\left(\mathrm{g} \times \mathrm{jar}^{-1}\right)$ : for pure crop of spring wheat -0.500 , for mixed crop of spring wheat and Persian clover -0.300 , and for Persian clover- 0.125 .

Soil moisture during growth was maintained at a constant level of $60 \%$ of the maximum water capacity and the water was replenished daily, if necessary.

When the spring wheat reached the appropriate growth stage, all plants were removed from the pots (intended for the given growth stage) and next the aboveground part was separated from the roots. The roots were carefully washed on screens and separated carefully. In the aboveground parts, stems, leaves, heads and inflorescences were separated. They were dried to air dry mass and weighed. Their yield from the individual growth stages was obtained in this way. The results obtained were also used for calculating the growth rate of spring wheat and Persian clover plants. Based on the dry mass, the biomass increment between the individual growth stages was determined for both species applying the formula [13]:

$$
\begin{aligned}
\mathrm{CGR} & =(\mathrm{dWc} / \mathrm{dt}) \times(1 / \mathrm{P}) \\
\text { where: } & \\
\mathrm{CGR}- & \text { crop growth rate } \\
\mathrm{dWc} & - \text { crop biomass increment ( } \mathrm{g} \text { of dry mass) } \\
\mathrm{dt} & - \text { time period during which the biomass } \\
& \text { increment occurred } \\
\mathrm{P} & - \text { area }\left(\mathrm{m}^{2}\right) .
\end{aligned}
$$

The results obtained were presented as average values from three series of the experiments. They were statistically analyzed by analysis of variance at a significance level of $p=0.05$. For evaluation of the differences between treatments, Tukey's test (HSD) was applied. The computations were made using Statistica software. 


\section{RESULTS}

\section{Biomass of spring wheat}

The sowing method had a significant influence on aboveground biomass of spring wheat during stem elongation and ripening (Table 1). The cultivation with Persian clover contributed to the development of shoots with lower mass than in pure crop cultivation by 17.5 and $21.0 \%$, respectively. During both periods, it was more pronounced in leaves than in stems, while during the ripening period the heads and grain showed the most negative response to this sowing method.
During the other growth stages, the relations between the sowing methods differed and took the form of a trend. The mixed cultivation of wheat with clover did not differentiate the root mass during the major part of the growing period. Better root development was found in mixed sowing compared to pure sowing (by 33.0\%) only during inflorescence emergence. The analysis of the total biomass (shoots + roots) of wheat showed that sowing method had a significant effect on it only during the ripening stage. Plants with lower mass developed in the mixed crop than in the pure crop (by $19.5 \%$ ).

Table 1

Spring wheat dry mass $\left(\mathrm{g} \times \operatorname{pot}^{-1}\right)$

\begin{tabular}{|c|c|c|c|c|c|c|c|c|c|}
\hline \multirow{4}{*}{$\begin{array}{l}\text { Growth stage } \\
(\mathrm{BBCH})\end{array}$} & \multirow{4}{*}{ Plant part } & \multicolumn{4}{|c|}{ Plant density } & \multirow{2}{*}{\multicolumn{2}{|c|}{$\begin{array}{l}\text { Average for plant } \\
\text { density }\end{array}$}} & \multirow{2}{*}{\multicolumn{2}{|c|}{$\begin{array}{l}\text { Average for sowing } \\
\text { method }\end{array}$}} \\
\hline & & \multicolumn{2}{|c|}{ recommended $(\mathrm{Z})$} & \multicolumn{2}{|c|}{ lower $(\mathrm{M})$} & & & & \\
\hline & & \multicolumn{4}{|c|}{ sowing method } & \multicolumn{2}{|c|}{ density } & \multicolumn{2}{|c|}{ sowing method } \\
\hline & & $\mathrm{C}^{*}$ & $\mathrm{~W}^{*}$ & $\mathrm{C}$ & $\mathrm{W}$ & $\mathrm{Z}$ & $\mathrm{M}$ & $\mathrm{C}$ & $\mathrm{W}$ \\
\hline \multirow{3}{*}{$\begin{array}{c}1 . \\
\text { Leaf development } \\
(12-14)\end{array}$} & leaves & $1.95 \mathrm{a}$ & $1.99 \mathrm{a}$ & $1.48 \mathrm{~b}$ & $1.72 \mathrm{a}$ & $1.97 \mathrm{a}$ & $1.60 \mathrm{~b}$ & $1.72 \mathrm{a}$ & $1.85 \mathrm{a}$ \\
\hline & roots & $0.82 \mathrm{a}$ & $0.73 \mathrm{a}$ & $0.54 \mathrm{a}$ & $0.57 \mathrm{a}$ & $0.78 \mathrm{a}$ & $0.56 \mathrm{a}$ & $0.68 \mathrm{a}$ & $0.65 \mathrm{a}$ \\
\hline & total & $2.77 \mathrm{a}$ & $2.72 \mathrm{a}$ & $2.02 \mathrm{a}$ & $2.29 \mathrm{a}$ & $2.75 \mathrm{a}$ & $2.16 \mathrm{a}$ & $2.40 \mathrm{a}$ & $2.50 \mathrm{a}$ \\
\hline \multirow{3}{*}{$\begin{array}{c}2 . \\
\text { Tillering } \\
(21-23) \\
\end{array}$} & leaves & $9.80 \mathrm{a}$ & $9.06 a$ & $8.21 \mathrm{a}$ & $8.01 \mathrm{a}$ & $9.43 \mathrm{a}$ & $8.11 \mathrm{~b}$ & $9.01 \mathrm{a}$ & $8.54 a$ \\
\hline & roots & $3.71 \mathrm{a}$ & $3.80 \mathrm{a}$ & $3.46 \mathrm{a}$ & $3.55 \mathrm{a}$ & $3.76 \mathrm{a}$ & $3.51 \mathrm{a}$ & $3.59 \mathrm{a}$ & $3.68 \mathrm{a}$ \\
\hline & total & $13.51 \mathrm{a}$ & $12.86 \mathrm{a}$ & $11.67 \mathrm{a}$ & $11.56 \mathrm{a}$ & $13.19 \mathrm{a}$ & $11.62 \mathrm{a}$ & $12.60 \mathrm{a}$ & $12.22 \mathrm{a}$ \\
\hline \multirow{5}{*}{$\begin{array}{c}3 . \\
\text { Stem elongation } \\
(31-32)\end{array}$} & stems & $7.13 \mathrm{a}$ & $6.54 b$ & $5.71 b c$ & $4.29 c$ & $6.84 a$ & $5.00 \mathrm{~b}$ & $6.42 \mathrm{a}$ & $5.42 b$ \\
\hline & leaves & $7.24 \mathrm{a}$ & $6.10 \mathrm{~b}$ & $7.16 \mathrm{a}$ & $5.53 \mathrm{bc}$ & $6.67 \mathrm{a}$ & $6.34 \mathrm{a}$ & $7.20 \mathrm{a}$ & $5.81 \mathrm{~b}$ \\
\hline & total & $14.37 \mathrm{a}$ & $12.64 \mathrm{ab}$ & $12.87 \mathrm{ab}$ & $9.82 b$ & $13.51 \mathrm{a}$ & $11.3 \mathrm{a}$ & $13.62 \mathrm{a}$ & $11.23 b$ \\
\hline & roots & $5.08 \mathrm{a}$ & $4.23 \mathrm{a}$ & $4.58 \mathrm{a}$ & $5.14 \mathrm{a}$ & $4.66 \mathrm{a}$ & $4.86 \mathrm{a}$ & $4.83 \mathrm{a}$ & $4.69 \mathrm{a}$ \\
\hline & total & $19.45 \mathrm{a}$ & $16.87 \mathrm{~b}$ & $17.45 \mathrm{ab}$ & $14.96 \mathrm{c}$ & $18.17 \mathrm{a}$ & $16.21 \mathrm{~b}$ & $18.45 \mathrm{a}$ & $15.92 b$ \\
\hline \multirow{6}{*}{$\begin{array}{c}5 . \\
\text { Inflorescence } \\
\text { emergence } \\
(54-56)\end{array}$} & stems & $7.49 a$ & $6.20 \mathrm{~b}$ & $7.38 \mathrm{a}$ & $6.54 \mathrm{ab}$ & $6.84 a$ & $6.96 a$ & $7.44 a$ & $6.37 b$ \\
\hline & leaves & $6.49 \mathrm{a}$ & $5.20 \mathrm{~b}$ & $6.63 a$ & $5.42 \mathrm{~b}$ & $5.85 \mathrm{a}$ & $6.03 a$ & $6.56 \mathrm{a}$ & $5.31 \mathrm{~b}$ \\
\hline & heads & $11.27 \mathrm{a}$ & $10.17 \mathrm{a}$ & $10.36 \mathrm{a}$ & $10.18 \mathrm{a}$ & $10.72 \mathrm{a}$ & $10.2 \mathrm{a}$ & $10.82 \mathrm{a}$ & $10.18 \mathrm{a}$ \\
\hline & total & $25.25 \mathrm{a}$ & $21.57 \mathrm{a}$ & $24.37 \mathrm{a}$ & $22.14 \mathrm{a}$ & $23.41 \mathrm{a}$ & $23.26 \mathrm{a}$ & $24.82 \mathrm{a}$ & $21.86 a$ \\
\hline & roots & $3.52 b$ & $5.17 \mathrm{a}$ & $3.64 \mathrm{~b}$ & $4.34 \mathrm{ab}$ & $4.35 \mathrm{a}$ & $3.99 \mathrm{a}$ & $3.58 \mathrm{~b}$ & $4.76 \mathrm{a}$ \\
\hline & total & $28.77 \mathrm{a}$ & $26.74 a$ & $28.01 \mathrm{a}$ & $26.48 \mathrm{a}$ & $27.76 \mathrm{a}$ & $26.2 \mathrm{a}$ & $28.39 \mathrm{a}$ & $26.62 \mathrm{a}$ \\
\hline \multirow{7}{*}{$\begin{array}{c}8 . \\
\text { Ripening } \\
(87-89)\end{array}$} & stems & $6.75 a$ & $5.52 b$ & $6.32 \mathrm{ab}$ & $5.53 \mathrm{~b}$ & $6.14 \mathrm{a}$ & $5.93 a$ & $6.54 a$ & $5.53 b$ \\
\hline & leaves & $5.96 \mathrm{a}$ & $4.65 c$ & $6.07 \mathrm{a}$ & $5.20 b c$ & $5.31 \mathrm{a}$ & $5.64 \mathrm{a}$ & $6.01 \mathrm{a}$ & $4.93 b$ \\
\hline & heads; including & $16.96 \mathrm{a}$ & $12.14 \mathrm{a}$ & $16.08 \mathrm{a}$ & $12.85 \mathrm{a}$ & $14.55 \mathrm{a}$ & $14.47 \mathrm{a}$ & $16.52 \mathrm{a}$ & $12.50 \mathrm{~b}$ \\
\hline & grains & $16.55 \mathrm{a}$ & $11.08 b$ & $15.94 \mathrm{ab}$ & $12.46 \mathrm{ab}$ & $13.82 \mathrm{a}$ & $14.20 \mathrm{a}$ & $16.25 \mathrm{a}$ & $11.77 \mathrm{~b}$ \\
\hline & total & $29.14 \mathrm{a}$ & $22.03 b$ & $28.63 \mathrm{a}$ & $23.74 b$ & $25.59 \mathrm{a}$ & $26.19 \mathrm{a}$ & $28.89 a$ & $22.89 b$ \\
\hline & roots & $2.72 \mathrm{a}$ & $2.63 \mathrm{a}$ & $2.84 \mathrm{a}$ & $2.76 \mathrm{a}$ & $2.68 \mathrm{a}$ & $2.80 \mathrm{a}$ & $2.78 \mathrm{a}$ & $2.69 \mathrm{a}$ \\
\hline & total & $31.86 \mathrm{a}$ & $24.66 \mathrm{~b}$ & $31.47 \mathrm{a}$ & $26.5 \mathrm{ab}$ & $28.27 \mathrm{a}$ & $28.99 \mathrm{a}$ & $31.67 \mathrm{a}$ & $25.58 \mathrm{~b}$ \\
\hline
\end{tabular}

$\mathrm{a}, \mathrm{b}, \mathrm{c}$ - values marked with the same letter do not differ significantly

* $\mathrm{C}$ - pure crop; $\mathrm{W}$ - cultivation as mixed crop with Persian clover

Aboveground biomass of wheat significantly depended on sowing density only during the two initial growth stages. The dry mass yield of plants growing at the recommended density was higher during the leaf development and tillering stages by $23.1 \%$ and $16.3 \%$, respectively, than in the case when the density was decreased by $20 \%$. During the other periods, this factor had no significant influence on the biomass of all analyzed aboveground parts of wheat. Plant density did not differentiate the root mass. The accumula- tion of dry mass in the whole plants of this cereal also depended to a lesser extent on sowing density. Their significantly higher mass was recorded in the pots with the recommended plant density (as compared to the density decreased by $20.0 \%$ ) only during the stem elongation stage.

The interaction of the experimental factors had a significant effect on dry mass accumulation in spring wheat shoots during the leaf development, stem elongation and ripening stages. During the two earlier stages, 
the differences between mixed and pure cropping occurred in the combination with the lower density. During the stem elongation stage, differences were shown in shoot and leaf mass. During ripening, an opposite situation was found. Larger differences between sowing methods (because of the stems, leaves and grain) were recorded in the treatment with the recommended density. During inflorescence emergence, mixed sowing reduced accumulation of dry mass in the stems more in the recommended density treatment than in the lower density treatment, but it did not differentiate its content in the leaves and in the heads. In the presence of clover, wheat developed a higher mass of roots than in pure crop sowing in the treatment with the recommended plant density. During the other stages, the density of plants did not change the relations between sowing methods in any significant way.

The interaction of experimental factors had no significant influence on the total biomass of the analysed cereal crop during the leaf development, tillering, and inflorescence emergence stages. During stem elongation, pure crop sowing was found to have a higher advantage over mixed sowing in case of the lower sowing density, while during ripening an opposite situation was observed.

\section{Biomass of Persian clover}

Both the aboveground parts and roots of Persian clover increased their mass until the end of the wheat growing period (Table 2). Grown together with spring wheat, Persian clover produced significantly lower aboveground mass than in pure sowing throughout the entire period of the study. The largest differences between pure sowing and mixed sowing (exceeding 80\%) were recorded during stem elongation and inflorescence emergence of wheat, while the smallest ones during the leaf development stage (almost 50\%). This decrease applied to a similar extent to the leaves, shoots and inflorescences, except the wheat inflorescence emergence stage when the largest differences between mixed and pure sowing

Table 2

Persian clover dry mass $\left(\mathrm{g} \times \mathrm{jar}^{-1}\right)$

\begin{tabular}{|c|c|c|c|c|c|c|c|c|c|}
\hline \multirow{4}{*}{$\begin{array}{c}\text { Wheat growth } \\
\text { stage } \\
(\mathrm{BBCH})\end{array}$} & \multirow{4}{*}{ Plant part } & \multicolumn{4}{|c|}{ Plant density } & \multirow{2}{*}{\multicolumn{2}{|c|}{$\begin{array}{l}\text { Average for plant } \\
\text { density }\end{array}$}} & \multirow{2}{*}{\multicolumn{2}{|c|}{$\begin{array}{l}\text { Average for sowing } \\
\text { method }\end{array}$}} \\
\hline & & \multicolumn{2}{|c|}{ recommended $(\mathrm{Z})$} & \multicolumn{2}{|c|}{ lower $(\mathrm{M})$} & & & & \\
\hline & & \multicolumn{4}{|c|}{ sowing method } & \multicolumn{2}{|c|}{ density } & \multicolumn{2}{|c|}{ sowing method } \\
\hline & & $\mathrm{C}^{*}$ & $\mathrm{~W}^{*}$ & $\mathrm{C}$ & $\mathrm{W}$ & $\mathrm{Z}$ & M & $\mathrm{C}$ & $\mathrm{W}$ \\
\hline \multirow{5}{*}{$\begin{array}{c}1 . \\
\text { Leaf development } \\
(12-14)\end{array}$} & leaves & $0.12 \mathrm{a}$ & $0.08 \mathrm{ab}$ & $0.10 \mathrm{a}$ & $0.04 \mathrm{~b}$ & $0.10 \mathrm{a}$ & $0.07 b$ & $0.11 \mathrm{a}$ & $0.06 \mathrm{~b}$ \\
\hline & stems & $0.10 \mathrm{a}$ & $0.06 \mathrm{~b}$ & $0.08 \mathrm{a}$ & $0.04 \mathrm{~b}$ & $0.08 \mathrm{a}$ & $0.06 \mathrm{a}$ & $0.09 \mathrm{a}$ & $0.05 b$ \\
\hline & total & $0.22 \mathrm{a}$ & $0.14 b$ & $0.18 \mathrm{a}$ & $0.08 \mathrm{~b}$ & $0.18 \mathrm{~b}$ & $0.13 b$ & $0.20 \mathrm{a}$ & $0.11 b$ \\
\hline & roots & $0.11 \mathrm{a}$ & $0.05 \mathrm{a}$ & $0.12 \mathrm{a}$ & $0.03 \mathrm{a}$ & $0.08 \mathrm{a}$ & $0.08 \mathrm{a}$ & $0.12 \mathrm{a}$ & $0.04 \mathrm{~b}$ \\
\hline & total & $0.33 \mathrm{a}$ & $0.19 \mathrm{~b}$ & $0.30 \mathrm{a}$ & $0.11 \mathrm{bc}$ & $0.26 \mathrm{a}$ & $0.21 \mathrm{~b}$ & $0.32 \mathrm{a}$ & $0.15 \mathrm{~b}$ \\
\hline \multirow{5}{*}{$\begin{array}{c}2 . \\
\text { Tillering } \\
(21-23)\end{array}$} & leaves & $1.16 \mathrm{a}$ & $0.30 \mathrm{~b}$ & $1.04 \mathrm{a}$ & $0.29 b$ & $0.73 a$ & $0.67 \mathrm{a}$ & $1.10 \mathrm{a}$ & $0.29 b$ \\
\hline & stems & $0.98 \mathrm{a}$ & $0.27 b$ & $0.82 \mathrm{a}$ & $0.23 \mathrm{~b}$ & $0.63 \mathrm{a}$ & $0.52 \mathrm{a}$ & $0.90 \mathrm{a}$ & $0.25 b$ \\
\hline & total & $2.14 \mathrm{a}$ & $0.57 \mathrm{~b}$ & $1.86 \mathrm{a}$ & $0.52 b$ & $1.36 \mathrm{a}$ & $1.19 \mathrm{a}$ & $2.00 \mathrm{a}$ & $0.54 \mathrm{~b}$ \\
\hline & roots & $0.56 \mathrm{a}$ & $0.16 \mathrm{c}$ & $0.41 \mathrm{~b}$ & $0.13 \mathrm{c}$ & $0.36 \mathrm{a}$ & $0.27 b$ & $0.49 \mathrm{a}$ & $0.15 b$ \\
\hline & total & $2.70 \mathrm{a}$ & $0.73 b$ & $2.27 \mathrm{a}$ & $0.65 b$ & $1.72 \mathrm{a}$ & $1.46 \mathrm{a}$ & $2.49 \mathrm{a}$ & $0.69 \mathrm{~b}$ \\
\hline \multirow{5}{*}{$\begin{array}{c}3 . \\
\text { Stem elongation } \\
(31-32)\end{array}$} & leaves & $3.32 \mathrm{a}$ & $0.36 \mathrm{~b}$ & $2.88 \mathrm{a}$ & $0.58 \mathrm{~b}$ & $1.84 \mathrm{a}$ & $1.73 \mathrm{a}$ & $3.10 \mathrm{a}$ & $0.47 \mathrm{~b}$ \\
\hline & stems & $2.44 \mathrm{a}$ & $0.33 b$ & $2.18 \mathrm{a}$ & $0.46 \mathrm{~b}$ & $1.38 \mathrm{a}$ & $1.32 \mathrm{a}$ & $2.31 \mathrm{a}$ & $0.39 \mathrm{~b}$ \\
\hline & total & $5.76 a$ & $0.69 b$ & $5.06 \mathrm{a}$ & $1.04 \mathrm{~b}$ & $3.22 \mathrm{a}$ & $3.05 \mathrm{a}$ & $5.41 \mathrm{a}$ & $0.86 \mathrm{~b}$ \\
\hline & roots & $0.82 \mathrm{a}$ & $0.22 \mathrm{c}$ & $0.52 b$ & $0.23 \mathrm{c}$ & $0.52 \mathrm{a}$ & $0.38 b$ & $0.67 \mathrm{a}$ & $0.23 b$ \\
\hline & total & $6.58 \mathrm{a}$ & $0.91 b$ & $5.58 \mathrm{a}$ & $1.27 \mathrm{~b}$ & $3.74 \mathrm{a}$ & $3.43 \mathrm{a}$ & $6.08 \mathrm{a}$ & $1.09 \mathrm{~b}$ \\
\hline \multirow{6}{*}{$\begin{array}{c}5 . \\
\text { Inflorescence } \\
\text { emergence } \\
(54-56)\end{array}$} & leaves & $6.67 \mathrm{a}$ & $1.51 \mathrm{~b}$ & $6.37 \mathrm{a}$ & $1.37 \mathrm{~b}$ & $4.09 a$ & $3.87 \mathrm{a}$ & $6.52 \mathrm{a}$ & $1.44 \mathrm{~b}$ \\
\hline & stems & $5.39 \mathrm{a}$ & $1.14 \mathrm{~b}$ & $4.91 \mathrm{a}$ & $1.04 \mathrm{~b}$ & $3.26 \mathrm{a}$ & $2.98 \mathrm{a}$ & $5.15 \mathrm{a}$ & $1.09 \mathrm{~b}$ \\
\hline & inflorescences & $2.27 \mathrm{a}$ & $0.25 b$ & $2.56 \mathrm{a}$ & $0.28 \mathrm{~b}$ & $1.26 \mathrm{a}$ & $1.42 \mathrm{a}$ & $2.42 \mathrm{a}$ & $0.27 b$ \\
\hline & total & $14.33 \mathrm{a}$ & $2.90 \mathrm{~b}$ & $13.84 \mathrm{a}$ & $2.69 \mathrm{~b}$ & $8.61 \mathrm{a}$ & $8.27 \mathrm{a}$ & $14.09 \mathrm{a}$ & $2.80 \mathrm{~b}$ \\
\hline & roots & $1.04 \mathrm{a}$ & $0.77 \mathrm{a}$ & $0.90 \mathrm{a}$ & $0.33 \mathrm{~b}$ & $0.91 \mathrm{a}$ & $0.61 b$ & $0.97 \mathrm{a}$ & $0.55 b$ \\
\hline & total & $15.37 \mathrm{a}$ & $3.67 \mathrm{~b}$ & $14.74 \mathrm{a}$ & $3.02 \mathrm{~b}$ & $9.52 \mathrm{a}$ & $8.88 \mathrm{a}$ & $15.06 \mathrm{a}$ & $3.35 \mathrm{~b}$ \\
\hline \multirow{6}{*}{$\begin{array}{c}8 . \\
\text { Ripening } \\
(87-89)\end{array}$} & leaves & $8.83 a$ & $3.02 \mathrm{c}$ & $7.77 b$ & $2.25 \mathrm{~d}$ & $5.93 a$ & $5.01 \mathrm{~b}$ & $8.30 \mathrm{a}$ & $2.64 b$ \\
\hline & stems & $7.45 \mathrm{a}$ & $2.80 \mathrm{c}$ & $6.18 b$ & $1.63 \mathrm{~d}$ & $5.12 \mathrm{a}$ & $3.90 \mathrm{~b}$ & $6.82 \mathrm{a}$ & $2.21 \mathrm{~b}$ \\
\hline & inflorescences & $3.81 \mathrm{a}$ & $1.36 \mathrm{~b}$ & $3.72 \mathrm{a}$ & $1.06 \mathrm{~b}$ & $2.59 \mathrm{a}$ & $2.39 \mathrm{a}$ & $3.76 \mathrm{a}$ & $1.21 \mathrm{~b}$ \\
\hline & total & $20.09 \mathrm{a}$ & $7.18 b$ & $17.67 \mathrm{a}$ & $4.94 b$ & $13.64 a$ & $11.30 \mathrm{a}$ & $18.88 \mathrm{a}$ & $6.06 \mathrm{~b}$ \\
\hline & roots & $1.27 \mathrm{a}$ & $0.78 \mathrm{ab}$ & $0.78 \mathrm{ab}$ & $0.59 \mathrm{~b}$ & $1.02 \mathrm{a}$ & $0.69 b$ & $1.03 \mathrm{a}$ & $0.69 \mathrm{~b}$ \\
\hline & total & $21.36 \mathrm{a}$ & $7.96 \mathrm{~b}$ & $18.45 \mathrm{a}$ & $5.53 \mathrm{~b}$ & $14.66 \mathrm{a}$ & $11.99 \mathrm{a}$ & $19.9 \mathrm{a}$ & $6.75 \mathrm{~b}$ \\
\hline
\end{tabular}

a, b, c - values marked with the same letter do not differ significantly

* $\mathrm{C}$ - pure crop; $\mathrm{W}$ - cultivation as mixed crop with Persian clover 
were recorded for the inflorescence mass. Mixed sowing also had a negative influence on the development of clover roots, but to a lower extent than in the case of shoots. Compared to pure sowing, on average for all the five wheat growth stages, the root mass was smaller by $49.4 \%$ (ranging from $33.0 \%$ at the end of growth to $69.4 \%$ at the wheat tillering stage). The poorer development of the aboveground parts and roots of clover in the mixture was reflected in the total mass of this crop. The cereal component reduced biomass accumulation by an average of $72.6 \%$ for all the stages. Its negative influence increased until the stem elongation stage during which the largest difference was recorded between mixed and pure crop (82.1\%). During the next stages, these differences decreased (down to $66.1 \%$ at the end of growth).

Plant density had no significant influence on the total aboveground biomass of clover plant throughout the entire growth period. A beneficial influence of the recommended sowing density on dry mass accumulation in clover leaves was noted during the leaf development and ripening stages of wheat and in shoots during ripening. This factor differentiated the root mass of clover from wheat tillering until ripening. In the treatment with the lower density, the roots were worse developed than in the one with the recommended density, on average by $30.6 \%$ (with variations from $25.0 \%$ at the tillering stage to $32.4 \%$ during ripening). Despite that the total Persian clover biomass (aboveground parts + roots) showed no significant changes under the influence of plant density during the major part of the grow- ing period. The recommended density had a favourable influence on biomass accumulation only during the leaf development stage.

Generally, sowing density had no influence on the magnitude of differences in dry mass accumulation in clover shoots and roots between mixed and pure sowing. It was only during the ripening stage that the wheat reduced biomass accumulation in clover shoots more in the treatment with the lower plant density.

\section{Growth rate of spring wheat and Persian clover plants}

Spring wheat had the highest mass growth rate per day in pure crop and mixed sowing during the stem elongation and inflorescence emergence stages as well as during leaf development and tillering stages (Table 3). During the entire growing period, no significant differences were recorded in the biomass accumulation rate depending on sowing method.

Plant density had a significant effect on the mass accumulation rate only in case of two interphases. During the sowing - leaf development interphase and during the stem elongation - inflorescence emergence interphase, plants growing at the lower density were characterized by faster biomass growth rates. At the same time, a clear increasing trend in the value of this parameter as a result of the decrease in plant density was observed until the stem elongation - inflorescence emergence interphase.

The differences in daily growth rates of spring wheat between sowing methods showed no significant correlation with plant density.

Table 3

Growth rate of spring wheat $\left(\mathrm{g}\right.$ dry mass $\times$ day $^{-1} \times$ pot $\left.^{-1}\right)$

\begin{tabular}{|c|c|c|c|c|c|c|c|c|}
\hline \multirow{4}{*}{ Interphase } & \multicolumn{4}{|c|}{ Plant density } & \multirow{2}{*}{\multicolumn{2}{|c|}{$\begin{array}{l}\text { Average for plant } \\
\text { density }\end{array}$}} & \multirow{2}{*}{\multicolumn{2}{|c|}{$\begin{array}{l}\text { Average for sowing } \\
\text { method }\end{array}$}} \\
\hline & \multicolumn{2}{|c|}{ recommended $(\mathrm{Z})$} & \multicolumn{2}{|c|}{ lower $(\mathrm{M})$} & & & & \\
\hline & \multicolumn{4}{|c|}{ sowing method } & \multicolumn{2}{|c|}{ density } & \multicolumn{2}{|c|}{ sowing method } \\
\hline & $\mathrm{C}^{*}$ & $\mathrm{~W}^{*}$ & $\mathrm{C}$ & $\mathrm{W}$ & $\mathrm{Z}$ & M & $\mathrm{C}$ & $\mathrm{W}$ \\
\hline Sowing - leaf development & $0.58 \mathrm{ab}$ & $0.56 b$ & $0.60 \mathrm{ab}$ & $0.62 \mathrm{a}$ & $0.57 b$ & $0.61 \mathrm{a}$ & $0.59 \mathrm{a}$ & $0.59 \mathrm{a}$ \\
\hline Leaf development - tillering & $3.23 \mathrm{a}$ & $4.37 \mathrm{a}$ & $3.60 \mathrm{a}$ & $2.70 \mathrm{a}$ & $3.80 \mathrm{a}$ & $3.15 \mathrm{a}$ & $3.42 \mathrm{a}$ & $3.54 \mathrm{a}$ \\
\hline Tillering - stem elongation & $2.85 \mathrm{a}$ & $2.86 \mathrm{a}$ & $2.70 \mathrm{a}$ & $3.90 \mathrm{a}$ & $2.86 \mathrm{a}$ & $3.30 \mathrm{a}$ & $2.78 \mathrm{a}$ & $3.38 \mathrm{a}$ \\
\hline $\begin{array}{l}\text { Stem elongation } \\
\text { - inflorescence development }\end{array}$ & $3.61 b$ & $3.42 \mathrm{~b}$ & $4.75 \mathrm{a}$ & $4.05 \mathrm{a}$ & $3.52 b$ & $4.40 \mathrm{a}$ & $4.18 \mathrm{a}$ & $3.74 \mathrm{a}$ \\
\hline Inflorescence development - ripening & $0.76 \mathrm{a}$ & $0.74 \mathrm{a}$ & $0.75 \mathrm{a}$ & $0.60 \mathrm{a}$ & $0.75 \mathrm{a}$ & $0.68 \mathrm{a}$ & $0.76 a$ & $0.67 \mathrm{a}$ \\
\hline
\end{tabular}

$\mathrm{a}, \mathrm{b}$ - values marked with the same letter do not differ significantly

* $\mathrm{C}$ - pure crop; $\mathrm{W}$ - cultivation as mixed crop with Persian clover

The presence of spring wheat reduced the Persian clover mass growth effectively from the beginning to the end of growth (Table 4). This was not confirmed by the statistical analysis only during inflorescence emergence - ripening. The aboveground biomass of clover increased fastest in the pure crop during the stem elongation - inflorescence emergence stage, whereas in case of the mixed crop during the inflorescence emergence - ripening interphase. The largest differences between pure and mixed sowing were recorded for tillering and stem elongation as well as for stem elongation and inflorescence emergence. 
Table 4

Growth rate of Persian clover (g dry mass · day 'ą · potą)

\begin{tabular}{|c|c|c|c|c|c|c|c|c|}
\hline \multirow{4}{*}{ Wheat interphases } & \multicolumn{4}{|c|}{ Plant density } & \multirow{2}{*}{\multicolumn{2}{|c|}{$\begin{array}{l}\text { Average for plant } \\
\text { density }\end{array}$}} & \multirow{2}{*}{\multicolumn{2}{|c|}{$\begin{array}{c}\text { Average for } \\
\text { sowing method }\end{array}$}} \\
\hline & \multicolumn{2}{|c|}{ recommended $(\mathrm{Z})$} & \multicolumn{2}{|c|}{ lower $(\mathrm{M})$} & & & & \\
\hline & \multicolumn{4}{|c|}{ sowing method } & \multicolumn{2}{|c|}{ density } & \multicolumn{2}{|c|}{ sowing method } \\
\hline & $\mathrm{C}^{*}$ & $\mathrm{~W}^{*}$ & $\mathrm{C}$ & $\mathrm{W}$ & $\mathrm{Z}$ & $\mathrm{M}$ & $\mathrm{C}$ & $\mathrm{W}$ \\
\hline Sowing - leaf development & $0.13 \mathrm{a}$ & $0.06 \mathrm{~b}$ & $0.08 \mathrm{ab}$ & $0.05 b$ & $0.10 \mathrm{a}$ & $0.07 \mathrm{a}$ & $0.11 \mathrm{a}$ & $0.06 \mathrm{~b}$ \\
\hline Leaf development - tillering & $0.84 \mathrm{a}$ & $0.23 b$ & $0.79 \mathrm{a}$ & $0.24 \mathrm{~b}$ & $0.54 \mathrm{a}$ & $0.52 \mathrm{a}$ & $0.82 \mathrm{a}$ & $0.24 \mathrm{~b}$ \\
\hline Tillering - stem elongation & $2.88 \mathrm{a}$ & $0.22 b$ & $3.44 \mathrm{a}$ & $0.42 b$ & $1.55 \mathrm{a}$ & $1.93 \mathrm{a}$ & $3.16 \mathrm{a}$ & $0.32 b$ \\
\hline $\begin{array}{l}\text { Stem elongation } \\
\text { - inflorescence development }\end{array}$ & $3.73 \mathrm{a}$ & $1.26 \mathrm{~b}$ & $3.32 \mathrm{a}$ & $0,87 \mathrm{~b}$ & $2.50 \mathrm{a}$ & $2.10 \mathrm{a}$ & $3.53 \mathrm{a}$ & $1.07 \mathrm{~b}$ \\
\hline Inflorescence development - ripening & $1.58 \mathrm{a}$ & $1.66 \mathrm{a}$ & $1.31 \mathrm{a}$ & $0.80 \mathrm{a}$ & $1.62 \mathrm{a}$ & $1.06 \mathrm{a}$ & $1.45 \mathrm{a}$ & $1.23 \mathrm{a}$ \\
\hline
\end{tabular}

$\mathrm{a}, \mathrm{b}$ - values marked with the same letter do not differ significantly

* C - pure crop; W - cultivation as mixed crop with Persian clover

The second factor of the experiment - plant density - had no significant effect on the clover growth rate during the entire growing period.

The effect of the interaction of both factors was significant from sowing until wheat inflorescence emergence without significant differences during the inflorescence emergence - ripening interphase. Mixed cultivation reduced the clover growth rate in both density treatments. In the combination with the lower density, a slower biomass accumulation rate was recorded in the mixed crop compared to the pure crop during the inflorescence emergence - ripening interphase, but the difference proved to be insignificant (although it was clearly noticeable).

\section{DISCUSSION}

In the present study, spring wheat growing in a mixture with Persian clover produced smaller biomass than in case of pure sowing during the stem elongation and ripening stages. During the remaining growing period, sowing method did not differentiate yield. $\mathrm{K} a ̈ \mathrm{nkänen}$ and Erikss on [3] also showed that clover was a weak competitor with spring barley and hence did not change its mass. Ofori and Stern [14] consider cereals to be stronger competitors than the papilionaceous plants, mainly because of the faster growth rate and higher density of roots, which is confirmed by our study. Maybe the roots of cereals absorb from the soil the nitrogen excreted by the roots of papilionaceous plants and that released during their decomposition [15]. This improves the condition of cereals and at the same time decreases the unfavourable influence of the competitor. $\mathrm{Mich}$ alsk a et al. [16] showed different results for the mixture of spring barley with peas. The study of those authors shows that the leguminous plant did not change the cereal biomass only during the initial development period, while during the further growth stages it limited its increase. In our study, the biomass of Persian clover cultivated together with spring wheat was lower than in pure cropping during the entire period of mixed cultivation. This is consistent with the study of Ć w in tal and Koście le cka [17] who obtained significantly lower biomass yields of red clover growing as the intercrop in the spring barley stand. In our experiment, the largest differences in the aboveground biomass produced between pure sowing and mixed sowing were obtained during wheat stem elongation and inflorescence development, while the earlier mentioned authors obtained such differences during ripening. Also S a t o r r e and S n a y d o n [18] showed that competition from cereals is strongest during Zadoks stages from 30 to 70 . S o b k ow i c z [19] showed that such an interaction between triticale and field bean was the most intensive during the period preceding grain filling. As a result of the dynamic development of cereal plants during this time, they reach a higher height than clover and hence catch more sunrays and this limits their access to clover and slows down its development. Thorsted et al. [4] show that up to a height of $20 \mathrm{~cm}$ of the stand, clover dominates in catching the light over wheat, but when the cereal becomes higher than clover, an opposite situation occurs. In our study, the lower biomass accumulation by the clover crop probably resulted also from the dominance of cereal over clover in terms of plant numbers in the mixture. By doubling the sowing density of field beans, S obk ow ic z [19] obtained an increase in its effect on triticale. The results of our own study showed a decrease in the negative effect of wheat on clover during the final period of growth, while the studies by $\mathrm{B} \mathrm{ul} 1$ s o n et al. [20], Michalska et al. [21], S obkow i c z [22], and Tre der et al. [23] also showed a decrease in the negative effect on the plants in the mixed stands consisting of other plant species. This is related to the differences in ripening time of different species. 
During the period when one species ends its growth its needs decrease and it absorbs fewer growth factors which become more available to the other species.

In our study, clover reduced aboveground biomass accumulation in wheat heads more than in leaves and stems. This resulted in the situation that in the analysed experiment the mass of wheat heads and grain in the mixture was lower by $24.3 \%$ and $27.6 \%$, respectively, than in the pure crop. The stronger influence of the competitor on the generative parts of plants than on the vegetative ones was also reported by $\mathrm{Mariotti}$ et al. [24]. A reduction in grain yield of spring wheat in case of its cultivation in a mixture with red clover and of winter wheat with white clover was also documented in the studies of $\mathrm{J}$ a s i e w i c z et al. [25] and Thorsted et al. [4]. On the other hand, other authors inform about a minor (or no) influence of papilionaceous plants on spring wheat and spring barley yields [26-30].

The reduction in aboveground mass of Persian clover plants in the mixture applied to a similar extent to the shoots, leaves and inflorescences, while in spring wheat (in addition to the above discussed yield of heads and grain) it applied to a greater extent to the leaves than to the stems. In case of wheat, it is consistent with the study by T red e $\mathrm{r}$ et al. [31]. On the other hand, L u c e ro et al. [32] found no influence of Trifolium repens on the leaf mass of Lolium perenne and its positive effect on stem shapeliness.

In both sowing methods, the mass of spring wheat roots was similar as opposed to Persian clover where in case of mixed sowing its reduction was recorded compared to the pure crop. This reduction, however, was smaller than the reduction in aboveground biomass. The weaker response of the roots of white lupin and sowing pea to mixed cultivation with cereals was also confirmed by $\mathrm{M}$ ariott $\mathrm{i}$ et al. [24] and Michalska et al. [16]. Different conclusions were reached by Kuras zkiewic z et al. [33] who found no influence of cereals on the root mass of interseeded species consisting of various papilionaceous plants species. The results obtained suggest that the competition for soil growth factors between cereals and papilionaceous plants is weaker than that for light.

In the presented experiment, Persian clover responded more than spring wheat to mixed cultivation by decreasing the biomass accumulation rate. On the other hand, the dynamics of wheat biomass growth was similar in case of both sowing methods. W a $\mathrm{n}$ i c et al. [34] also did not prove the influence of intercrops on the daily growth of barley. This probably results from the architecture of the stand of the analysed mixture. Higher wheat plants inhibited the development of lower clover plants by limiting access of the sun to the legume crop. This is proven by the studies of A t i s et al. [11] and Mariotti et al. [24] who showed that vetch, after reaching a higher height, and lupine being more vigorous than wheat plants became stronger competitors for wheat. The limiting influence of higher pea plants on lower barley plants was also documented in the study by Michalska et al. [21]. Sobkowicz and Lejman [35] share this opinion. They showed that abundant growth of Persian clover was the reason for its effect on spring barley (it grew higher than the cereal crop).

Plant density had no effect or had a slight differentiating effect on dry biomass production of spring wheat and Persian clover. Also Känkänen and Eriks s on [28] found no clear correlation between the number of papilionaceous plants sown and barley yield. According to Thorsted et al. [4], increasing the distance between rows decreased competition for light, which translated into better growth of wheat aboveground biomass. In case of red clover, Ćwintal and Kościelecka [17] also obtained a significant increase in dry mass with an increase in seeds. This is also confirmed by the study of A t is et al. [11] concerning a vetch and wheat mixture. $\mathrm{H}$ ar a [36], Sowiński et al. [37] and Schimtt and $\mathrm{Wulff}[38]$ also demonstrate the positive effect of higher plant density on plant biomass. In the experiment in question, plant density did not influence the biomass accumulation rate, either. This is consistent with the study by S o b k ow i c z [21]. He showed that the plant growth rate in mixed cultivation of cereals was similar during the major part of the growing period to that in pure cropping.

\section{CONCLUSIONS}

1. The aboveground mass of spring wheat cultivated with Persian clover was lower than in pure cropping during the stages of stem elongation and ripening. During the other growth periods, the aboveground mass of this cereal showed no variation due to sowing method.

2. During the leaf development and stem elongation stages, mixed sowing reduced dry mass accumulation more in the treatment with the lower plant density, while during ripening - in the treatment with the recommended density.

3. In the mixed crop, biomass accumulation in the shoots and roots of Persian clover was lower than in the pure crop during the entire growing period.

4. Sowing method did not differentiate the spring wheat growth rate, as opposed to Persian clover in case of which the daily biomass increments in the mixed crop were smaller than in the pure crop until the inflorescence development and cereal ripening interphase. 


\section{Acknowledgements}

This paper was prepared using funds allocated for statutory research of the University of Warmia and Mazury in Olsztyn (subject number: 1016-0819).

\section{Authors' contributions}

Concept: MW; execution of the study and analysis of results: MW, MM; writing the paper: MW, MM.

\section{REFERENCES}

1. Jaskulski D, Jaskulska I. Bioróżnorodność agroekosystemów i krajobrazu rolniczego a polowa produkcja roślinna. Post Nauk Roln. 2006; 4: 43-57.

2. Jaskulska J, Gałęzewski L. Aktualna rola międzyplonów w produkcji roślinnej i środowisku. Fragm Agron. 2009; 26(3): 48-57.

3. Känkänen H, Eriksson C. Effects of undersown crops on soil mineral $\mathrm{N}$ and grain yield of spring barley. Eur J Agron. 2007; 27(1): 25-34. http://dx.doi.org/10.1016/j.eja. 2007.01.010

4. Thorsted MD, Olesen JE, Weiner J. Width of clover strips and wheat rows influence grain yield in winter wheat/white clover intercropping. Field Crops Res. 2006; 95(2-3): 280-290. http://dx.doi.org/10.1016/j.fcr.20 05.04 .001

5. Galon L, Tironi S., Rocha PR., Concenço G, Silva A., Vargas L, et al. Habilidade competitiva de cultivares de cevada convivendo com azevém. Planta Daninha. 2011; 29(4): 771-781. http://dx.doi.org/10.1590/ S0100-83582011000400007

6. Sobkowicz P, Podgórska-Lesiak M. Ocena oddziaływania jęczmienia uprawianego w mieszance $\mathrm{z}$ pszenżytem lub grochem w zależności od dawki nawożenia azotem. Fragm Agron. 2009; 26(1): 115-126.

7. Wanic M, Jastrzębska M, Kostrzewska MK, Tre de r K. Competition between spring barley (Hordeum vulgare L.) and italian ryegrass (Lolium multiflorum Lam.) under different water supply conditions. Acta Agrobot. 2013; 66(3): 73-80. http://dx.doi.org/10.5586/aa.2013.040

8. Wanic M, Kostrzewska MK, Jastrzębska M, Treder K. Influence of competitive interactions between spring barley (Hordeum vulgare L.) and italian ryegrass (Lolium multiflorum LAM) on accumulation of biomass and growth rate of plants depending on water doses. Pol J Nat Sci. 2013; 28(1): 17-30.

9. Yachi S, Loreau M. Does complementary resource use enhance ecosystem functioning? A model of light competition in plant communities: light-use complementarity and complementarity index. Ecol Lett. 2007; 10(1): 54-62. http://dx.doi.org/10.1111/j.1461-0248.2006.00994.x

10. S obkow ic z P. Pobieranie i wykorzystanie azotu w uprawie jęczmienia jarego z wsiewką koniczyny perskiej i seradeli. Probl Inż Rol. 2009; 2: 99-106.
11. Atis I, Kokten K, Hatipoglu R, Yilmaz S, A t a k M, C a n E. Plant density and mixture ratio effects on the competition between common vetch and wheat. Aust J Crop Sci. 2012; 6(3): 498-505.

12. Semere T, Froud-Williams RJ. The effect of pea cultivar and water stress on root and shoot competition between vegetative plants of maize and pea. J Appl Ecol. 2001; 38(1): 137-145. http://dx.doi.org/10.1046/j.1365-266 4.2001.00570.x

13. Radford PJ. Growth analysis formulae - their use and abuse. Crop Sci. 1967; 7(3): 171-175. http://dx.doi. org/10.2135/cropsci1967.0011183X000700030001x

14. O for i F, Ster n W R. Cereal-legume intercropping systems. Adv Agron. 1987; 41: 41-90.

15. Hauggaard-Nielsen H, Ambus P, Jensen ES. Interspecific competition, $\mathrm{N}$ use and interference with weeds in pea-barley intercropping. Field Crops Res. 2001; 70(2): 101-109. http://dx.doi.org/10.1016/S0378-42 90(01)00126-5

16. Michalska M, Wanic M, Kostrzewska MK. Konkurencja pomiędzy jęczmieniem jarym a grochem siewnym w zróżnicowanych warunkach glebowych. Cz. I. Akumulacja biomasy i tempo wzrostu roślin. Acta Sci Pol Agric. 2008; 7(2): 69-86.

17. Ćwintal M, Kościelecka D. Wpływ sposobu i ilości wysiewu nasion na strukturę zagęszczenia, plonowanie oraz jakość di- i tetraploidalnej koniczyny czerwonej w roku siewu. Część II. Plonowanie oraz jakość. Biul IHAR. 2005; (237-238): 249-258.

18. Satorre EH, Snaydon RW. A comparison of root and shoot competition between spring cereals and Avena fatua L. Weed Res. 1992; 32(1): 45-55. http://dx.doi.org/ 10.1111/j.1365-3180.1992.tb01861.x

19. Sobkowicz P. Competition between triticale (Triticosecale Witt.) and field beans (Vicia faba var. minor L.) in additive intercrops. Plant Soil Env. 2006; 52(2): 47-54.

20. Bulson HAJ, Snaydon RW, Stopes CE. Effects of plant density on intercropped wheat and field beans in an organic farming system. J Agric Sci. 1997; 128(1): 59-71. http://dx.doi.org/10.1017/S0021859696003759

21. Michalska M, Wanic M, Jastrzębska M.Konkurencja pomiędzy jęczmieniem jarym a grochem siewnym w zróżnicowanych warunkach glebowych. Cz. II. Intensywność oddziaływań konkurencyjnych. Acta Sci Pol Agric. 2008; 7(2): 87-99.

22. Sobkowicz P. Konkurencja międzygatunkowa w jarych mieszankach zbożowych. Zesz Nauk AR Wroc Rozpr. 2003; CXCIV: 5-105.

23. Treder K, Wanic M, Nowicki J. The intensity of competitive interactions between spring wheat (Triticum aestivum L. emend. Fiori et. Paol) and spring barley (Hordeum vulgare L.) under different fertilisation conditions. Acta Agrobot. 2008; 61(2): 195-203. http://dx.doi.org/ 10.5586/aa.2008.048

24. Mariotti M, Masoni A, Ercoli L, Arduini I. Above- and below-ground competition between barley, wheat, lupin and vetch in a cereal and legume intercropping 
system. Grass Forage Sci. 2009; 64(4): 401-412. http:// dx.doi.org/10.1111/j.1365-2494.2009.00705.x

25. Jasiewicz C, Zając T, Sendor R, Witkowicz $R$. Oddziaływanie wsiewek na plon i skład chemiczny roślin ochronnych uprawianych w różnych warunkach siedliska. Zesz Probl Post Nauk Rol. 1995; 421a: 151-161.

26. Bergkvist G, Stenberg M, Wetterlind J, Bíth B, Elfstrand S. Clover cover crops under-sown in winter wheat increase yield of subsequent spring barley - effect of $\mathrm{N}$ dose and companion grass. Field Crops Res. 2011; 120(2): 292-298. http://dx.doi.org/10.1016/j. fcr.2010.11.001

27. Garand MJ, Simard RR, Mackenzie AF, $\mathrm{Hamel} \mathrm{C}$. Underseeded clover as a nitrogen source for spring wheat on a Gleysol. Can J Soil Sci. 2001; 81(1): 93102. http://dx.doi.org/10.4141/S99-060

28. Känkänen H, Eriksson C, Räkköläinen M. Effect of annually repeated undersowing on cereal grain yields. Agric Food Sci. 2008; 10(3): 197-208.

29. Olesen JE, Hansen EM, Askegaard M, Rasmussen IA. The value of catch crops and organic manures for spring barley in organic arable farming. Field Crops Res. 2007; 100(2-3): 168-178. http://dx.doi.org/10.1016/j. fcr.2006.07.001

30. Spaner D, Todd AG. The impact of underseeding forage mixtures on barley grain production in northern North America. Can J Plant Sci. 2003; 83(2): 351-355. http://dx. doi.org/10.4141/P02-034

31. Treder K, Wanic M, Nowicki J. Competitive between spring wheat and spring barley under conditions of diversified fertilization. Part 2. Influence on biomass of plants and rate of its accumulation. Acta Agroph. 2008; 11(3): 781-797.

32. Lucero D., Grieu P, Guckert A. Water deficit and plant competition effects on $14 \mathrm{C}$ assimilate partitioning in the plant-soil system of white clover (Trifolium repens L.) and rye-grass (Lolium perenne L.). Soil Biol Biochem. 2002; 34(1): 1-11. http://dx.doi.org/10.1016/S0038-0717 (01)00116-X

33. Kuraszkiewicz R, Pałys E, Kraska P. Następczy wpływ roślin ochronnych na masę korzeniową wsiewek śródplonowych na glebie lekkiej. Acta Agroph. 2006; 8(3): 663-669.

34. Wanic M, Michalska M, Treder K. Spring barley overground biomass increase dynamics depending on sowing method and position in crops rotation system. Pol J Nat Sci. 2009; 20(1): 67-79.

35. Sobkowicz P, Lejman A. Reakcja jęczmienia jarego oraz wsiewek koniczyny perskiej i seradeli na nawożenie azotem. Fragm Agron. 2011;28(1):50-61.

36. Hara T. Dynamics of stand structure in plant monocultures. J Theor Biol. 1984; 110(2): 223-239. http://dx.doi. org/10.1016/S0022-5193(84)80055-7

37. Sowiński J, Nowak W, Liszka-Podkowa A. Wpływ nawożenia azotem i sposobu siewu na plonowanie koniczyny perskiej i życicy westerwoldzkiej w porównaniu z mieszanką pszenżyta z grochem. Acta Sci Pol Agric. 2006; 5(2): 89-97.

38. Schmitt J, Wulff RD. Light spectral quality, phytochrome and plant competition. Trends Ecol Evol. 1993; 8(2): 47-51. http://dx.doi.org/10.1016/0169-5347(93)90157-K

\section{Zmiany w biomasie}

pszenicy jarej (Triticum aestivum ssp. vulgare L.) i koniczyny perskiej (Trifolium resupinatum L.) pod wpływem konkurencji i zagęszczenia roślin

\section{Streszczenie}

W doświadczeniu wazonowym, zrealizowanym w trzech seriach w latach 2010-2012 oceniano wpływ sposobu siewu i zagęszczenia roślin na biomasę pędów i korzeni pszenicy jarej i koniczyny perskiej. Rośliny uprawiano w mieszance i siewie czystym w zagęszczeniu większym (zgodnym z zalecaniami agrotechniki) i zmniejszonym w stosunku do niego o 20\%. Badania akumulacji suchej masy u obu gatunków przeprowadzano w okresach rozwojowych pszenicy jarej $(\mathrm{BBCH})$ : rozwój liści (12-14), krzewienie (21-23), strzelanie w źdźbło (31-32), kłoszenie (54-56) i dojrzewanie (87-89). Na podstawie uzyskanych wyników oznaczono również tempo przyrostu masy obu gatunków pomiędzy badanymi okresami. Wykazano, że masa pędów pszenicy jarej uprawianej w mieszance z koniczyną perską była mniejsza niż w siewie czystym w fazach strzelania w źdźbło i dojrzewania. W pozostałych okresach wegetacji nie wykazywała ona zróżnicowań pod wpływem sposobu siewu. Siew mieszany najbardziej ograniczał akumulację nadziemnej biomasy w kłosach i ziarnie, a najmniej w źdźbłach. W fazie rozwoju liści i strzelania w źdźbło pszenica silniej zareagowała na obecność koniczyny spadkiem biomasy na obiekcie z mniejszym zagęszczeniem roślin, a podczas dojrzewania - z zalecanym. Masa korzeni pszenicy w obu sposobach siewu i zagęszczenia roślin była podobna. W mieszance akumulacja biomasy w pędach i korzeniach koniczyny perskiej była mniejsza niż w siewie czystym w całym okresie wegetacji. Pszenica najbardziej ograniczała jej gromadzenie w kwiatostanach, a najmniej w korzeniach. Tempo wzrostu pszenicy jarej w obu sposobach siewu było podobne, w przeciwieństwie do koniczyny perskiej, u której w mieszance stwierdzono jego zmniejszenie w okresie rozwoju generatywnego zboża. U obu gatunków, różnice w tempie akumulowania biomasy między sposobami siewu nie zależały od zagęszczenia roślin. 
Handling Editor: Elżbieta Weryszko-Chmielewska

This is an Open Access digital version of the article distributed under the terms of the Creative Commons Attribution 3.0 License (creativecommons.org/licenses/by/3.0/), which permits redistribution, commercial and non-commercial, provided that the article is properly cited.

CThe Author(s) 2014 Published by Polish Botanical Society 